\title{
ТЕХНИКО-ТЕХНОЛОГИЧЕСКИЕ
} ИННОВАЦИИ

УДК 629.33

ББК 39.33

\section{CALCIUM SOAP LUBRICANTS}

\author{
Alaz Izer \\ Undergraduate Senior Year Student, Department of Chemical Engineering, \\ Izmir Institute of Technology \\ devrimbalkose@gmail.com \\ Gulbahcekoyu Urla 2, 35430 Izmir, Turkey
}

\section{Tugce Nefise Kahyaoglu}

Undergraduate Senior Year Student, Department of Chemical Engineering, Izmir Institute of Technology

devrimbalkose@gmail.com

Gulbahcekoyu Urla 2, 35430 Izmir, Turkey

\section{Devrim Balköse}

Doctor of Chemical Sciences, Head of the Department of Chemical Engineering, Izmir Institute of Technology devrimbalkose@gmail.com Gulbahcekoyu Urla 2, 35430 Izmir, Turkey

\begin{abstract}
The article studies the properties of calcium stearate $\left(\mathrm{CaSt}_{2}\right)$ and lubricants produced on its basis. These lubricants were prepared using sodium stearate and calcium chloride by subsidence from aqueous solutions. The $\mathrm{CaSt}_{2}$ and the light fraction of crude oil were mixed together to obtain lubricating substances. The article shows that $\mathrm{CaSt}_{2}$ had the melting temperature of $142.8^{\circ} \mathrm{C}$ that is higher than the melting temperature of crude oil $\left(128^{\circ} \mathrm{C}\right)$. The compositions of obtained lubricants were studied with optical microscopes. The article shows that the sizes of dispersed particles amount to $1.88 \mathrm{mcm}$ and $0.11 \mathrm{mcm}$ for lubricants having $1 \%$ and $2 \% \mathrm{CaSt}_{2}$ concentration, respectively. As a result of wear trials, it was shown that the friction and wear coefficients of crude oil amounted to 0.099 and $1402 \mathrm{~nm}$, respectively. For the lubricant with $1 \% \mathrm{CaSt}_{2}$ concentration, these coefficients were reduced
\end{abstract}


to 0.0730 and $627.61 \mathrm{~nm}$. Lower wear coefficient $(540 \mathrm{~nm})$ was obtained for the lubricant with $2 \% \mathrm{CaSt}_{2}$ concentration. The $\mathrm{CaSt}_{2}$ improved the lubricating property of crude oil but did not improve its oxidative and thermal stability.

Key words: lubricant, calcium stearate, crude oil, friction coefficient, melting temperature.

\section{INTRODUCTION}

A lubricant provides a protective film which allows for two touching surfaces to be separated, thus lessening the friction between them. Lubricating oil is a liquid lubricant that reduces friction, protects against corrosion, reduces electric currents and cools machinery temperature. It is most often used in the automobile industry and is applied to bearings, dies, chains, cables, spindles, pumps, rails and gears to make them run smoother and more reliable. Lubricating oil is a substance introduced between two moving surfaces to reduce the friction and wear between them. Lubricating oils consist of a liquid paraffinic or vegetable oil and surface active agents, antioxidants and anticorrosive additives. Metal soaps in pure form or dispersed in paraffinic oils are used as lubricants. Felder et al [3] used sodium and calcium soap coatings on steel wires for drawing the wires. Calcium stearate had good lubricating efficiency at low wire drawing rates [ibid.]. The possibility for the production of a motor oil with improved operating characteristics and a higher stability by applying composite additives has been studied by Palichev et al [8]. For this purpose two multifunctional additives, synthesized by them have been used. They used additives containing calcium stearate and calcium salts of nitrated polypropylene and oxidized paraffin, urea, ethylene diammine, stearic acid. The additives improved the anticorrosion, viscosity-temperature, antiwear and antisludge properties of the lubricant [ibid.]. The optimum concentration of the additive, which enables the production of a high-quality motor lubricant, has been found to be $5 \%$ [ibid.]. Cutting oils were obtained by adding $\mathrm{CaSt}_{2}$ to dry paraffin oil up to $5 \%$ together with other additives [5]. Thus the gelation was prevented and an easily flowing cutting oil was obtained. Savrik et al [9] prepared lubricants using base oil, surface active agent Span 60 and zinc borate particles. They used $1 \%$ Span 60 and $1 \%$ zinc borate. Surface active agent Span 60 was found to be very effective in reducing the friction coefficient and wear scar diameter in four ball tests. As surface active agents metal soaps are also used. Metal soaps are transition metal salts of the fatty acids and the alkaline earth elements. Although, the alkali salts of the fatty acids such as sodium and potassium are water soluble, metal soap is water insoluble but more soluble in non-polar organic solvents. Calcium stearate $\mathrm{Ca}\left(\mathrm{C}_{17} \mathrm{H}_{35} \mathrm{COO}\right)_{2}$, in short form $\mathrm{CaSt}_{2}$ is the one of the important ionic surfactants of metal soaps. Calcium Stearate, is a non-toxic, white powdery substance. It is a calcium salt derived from stearic acid and is widely used in cosmetics, plastics,pharmaceuticals and lubricants [4].

Metal soaps can be obtained by neutralization of long chain organic acids with bases or by precipitation process. More ria et al [7] investigated formation of $\mathrm{CaSt}_{2}$ from stearic acid and calcium hydroxide in different solvents and a complete conversion to $\mathrm{CaSt}_{2}$ was obtained in ethanol medium [ibid.]. The precipitation process generally produces metal soap in powder form by the reaction of aqueous solutions of water soluble metal salt and fatty acid alkali metal salt at a temperature below the boiling point of water atatmospheric pressure. Filtering, washing, drying are the important steps in this method.Calcium stearate is produced in pure form by using this process [4].

Production of a lubricant by using a neutral base oil and calcium stearate is the aim of this study. The lubricating effects were tested by a four ball tester for this purpose.

\section{MATERIALS AND THE METHOD}

\section{Materials}

Calcium chloride, $\mathrm{CaCl}_{2} \cdot 2 \mathrm{H}_{2} \mathrm{O}(98 \%$, Aldrich), and sodium stearate $(\mathrm{NaSt})$, $\mathrm{C}_{17} \mathrm{H}_{35} \mathrm{COONa}$ (commercial product, Dalan Kimya A.S., Turkey), were used in the synthesis of $\mathrm{CaSt}_{2}$. The acid value of stearic acid, used in the NaSt synthesis, was $208.2 \mathrm{mg}$ of $\mathrm{KOH} / \mathrm{g}$ of stearic acid and it consists of a $\mathrm{C}_{16}-\mathrm{C}_{18}$ alkyl chain 
and with $47.7 \%$ and $52.3 \%$ by weight, respectively [4].

Spindle Oil from TUPRAS Izmir was used as base oil in the preparation of the lubricants.

\section{Preparation of calcium stearate powder}

Calcium stearate powder was prepared from sodium stearate and calcium chloride by precipitation from aqueous solutions according to reaction 1 .

$$
\begin{aligned}
& 2 \mathrm{C}_{17} \mathrm{H}_{35} \mathrm{COO}^{-+} \mathrm{Na}_{(\mathrm{aq})}+\mathrm{Ca}^{2+}{ }_{(\mathrm{aq})} \rightarrow \\
& \rightarrow\left(\mathrm{C}_{17} \mathrm{H}_{35} \mathrm{COO}\right)_{2} \mathrm{Ca}_{(\mathrm{s})}+2 \mathrm{Na}^{+}{ }_{(\mathrm{aq})} .
\end{aligned}
$$

$5.000 \mathrm{~g}(0.016 \mathrm{~mol})$ of sodium stearate, (NaSt) was dissolved in $200 \mathrm{~cm}^{3}$ of deionized water in a stainless steel reactor at $75^{\circ} \mathrm{C} .1 .7984 \mathrm{~g}$ (0.012 mol) of calcium chloride (50\% excess) was dissolved in $100 \mathrm{~cm}^{3}$ of deionized water at $30{ }^{\circ} \mathrm{C}$ and added to sodium soap solution at $75^{\circ} \mathrm{C}$. The mixture was stirred at a rate of $500 \mathrm{rpm}$ at $75{ }^{\circ} \mathrm{C}$ by a mechanical stirrer for $30 \mathrm{~min}$. Since the by-product, $\mathrm{NaCl}$, is soluble in water the reaction media was filtered by using Büchner funnel and flask under $600-\mathrm{mm} \mathrm{Hg}$ vacuum level. To remove the $\mathrm{NaCl}$ completely, wet $\mathrm{CaSt}_{2}$ was washed by $200 \mathrm{~cm}^{3}$ deionized water once and then, wet $\mathrm{CaSt}_{2}$ cake was dried in a vacuum oven under $2 \times 10^{4} \mathrm{~Pa}$ pressure. The $\mathrm{KBr}$ disc spectrum of the powder was taken with Shimadzu FTIR spectrophotometer. The SEM micrograph of the dried powder was taken with Scanning electron microscopy (Philips XL30 SFEG).

\section{Lubricant preparation}

$1 \mathrm{~g}$ of $\mathrm{CaSt}_{2}$ and $100 \mathrm{~cm}^{3}$ spindle oil were mixed together at $160{ }^{\circ} \mathrm{C}$ at 880 revolution $\mathrm{min}^{-1}$ rate for 30 minutes and then cooled to $25^{\circ} \mathrm{C}$ by continuously stirring. At the mixing experiments, a heater and magnetic stirrer (Ika Rh Digital KT/C) and a thermocouple (IKAWerke) were used. The experiment was repeated with $2 \mathrm{~g}$ of $\mathrm{CaSt}_{2}$ in $100 \mathrm{~cm}^{3}$ oil.

\section{Lubricant characterization}

The dispersion of $\mathrm{CaSt}_{2}$ in base oil was observed by optical microscopy. The phase change behavior of $\mathrm{CaSt}_{2}$ and lubricants with increasing temperature was observed with an optical microscope equipped with a hot plate. The stabilities of the lubricants having different calcium stearate contents were determined by measuring the rate of settling calcium stearate particles in base oils. The chemical structures of calcium stearate and the prepared lubricants were investigated by FTIR spectroscopy. The tribologic behavior of the lubricants was tested with a four ball tester. Four ball tests were done using the four ball tester from DUCOM Corporation (Figure 1) to determine the friction coefficient and wear scar diameter of the lubricants. The test was performed according to ASTM D 4172-94 at $392 \mathrm{~N}$ and $1200 \mathrm{rpm}$ and the test duration was $1 \mathrm{~h}$. The wear scar diameter was reported as the average of the wear scar diameter of the three fixed balls.

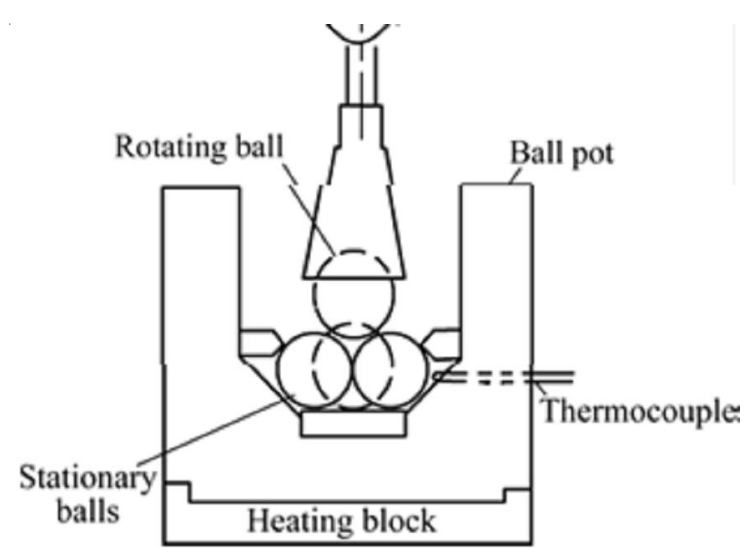

Fig. 1. Four ball tester

The visible spectrum of base oil separated by centrifugation from base oil was taken by using Perkin Elmer UV-Vis spectrophotometer by using base oil without any additive as the reference.

\section{Optical microscope}

Melting behavior of $\mathrm{CaSt}_{2}$ in powder form and in dispersed form in the base oil on a microscope slide was observed by using the transmission optical microscope (Olympus, CH40) with a heated hot stage controlled by a temperature controller (Instec, STC 200C). The samples were heated at $5{ }^{\circ} \mathrm{C} / \mathrm{min}$ rate from room temperature up to $190{ }^{\circ} \mathrm{C}$. The photographs were taken with Camedia Master Olympus Digital camera. 


\section{ТЕХНИКО-ТЕХНОЛОГИЧЕСКИЕ ИННОВАЦИИ}

\section{RESULTS AND DISCUSSION}

\section{$\mathrm{CaSt}_{2}$ powders}

FTIR spectrum of calcium stearate powder obtained by precipitation process is shown in Figure 2. The characteristic peaks of calcium stearate at $1542 \mathrm{~cm}^{-1}$ and $1575 \mathrm{~cm}^{-1}$ were observed. These bands are due to antisymmetric stretching bands for unidendate and bidendate association of carboxylate groups with calcium ions [4; 6]. Antisymmetric and symmetric methylene stretching, and methylene scissoring bands $\left(\mathrm{v}_{\mathrm{a}} \mathrm{CH}_{2}\right.$, $v_{\mathrm{s}} \mathrm{CH}_{2}$, and $\delta_{\mathrm{s}} \mathrm{CH}_{2}$ ) were observed at about $2914 \mathrm{~cm}^{-1}, 2850 \mathrm{~cm}^{-1}$ and $1472 \mathrm{~cm}^{-1}$ respectively. These bands are due to the alkyl chain in the calcium stearate structure $[4 ; 6]$.

The SEM micrograph of the $\mathrm{CaSt}_{2}$ powder shown in Figure 3 indicated that the particles were flat in shape and had a broad size distribution ranging from $200 \mathrm{~nm}$ to $1 \mu \mathrm{m}$. The average diameter of particles was $600 \mathrm{~nm}$.

\section{FTIR spectra of lubricants}

The prepared lubricants were also examined by FTIR spectroscopy. Their FTIR spectra are shown in Figure 4. The peaks at 2918 and $2848 \mathrm{~cm}^{-1}, 1454 \mathrm{~cm}^{-1}$ are due to stretching and bending vibrations of the methylene groups in base oil structure. The stretching and bending vibrations of the methyl group are observed at 2951 and $1385 \mathrm{~cm}^{-1}$. At $3414 \mathrm{~cm}^{-1}$ a broad peak related to hydrogen bonded $\mathrm{OH}$ groups is present. The antisymmetric stretching bands for unidendate and bidendate association of carboxylate groups with calcium ions at $1542 \mathrm{~cm}^{-1}$ and $1575 \mathrm{~cm}^{-1}$ are observed as small peaks in the spectra.

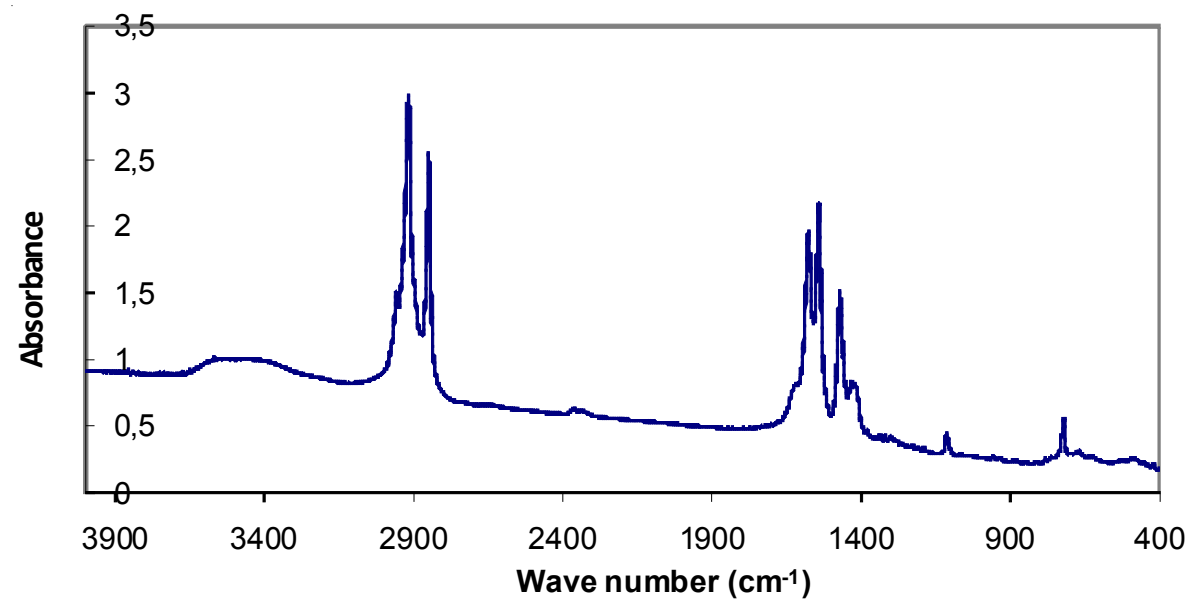

Fig. 2. FTIR spectrum of bulk $\mathrm{CaSt}_{2}$

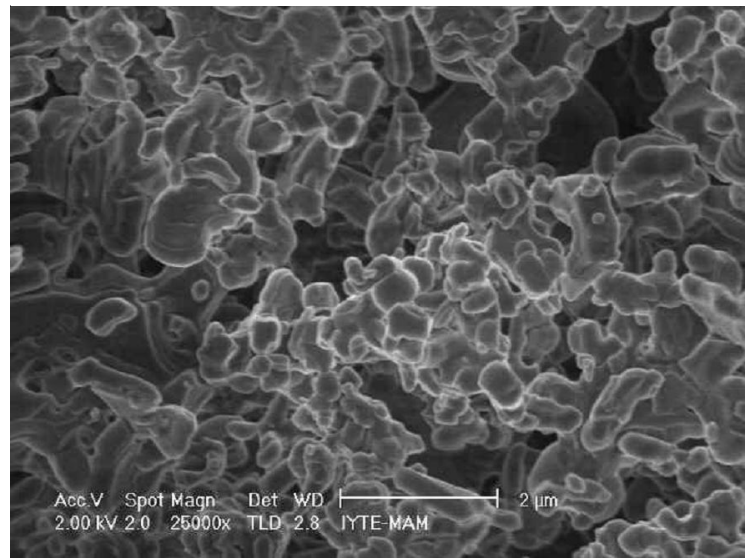

Fig. 3. SEM micrograph of $\mathrm{CaSt}_{2}$ powder 


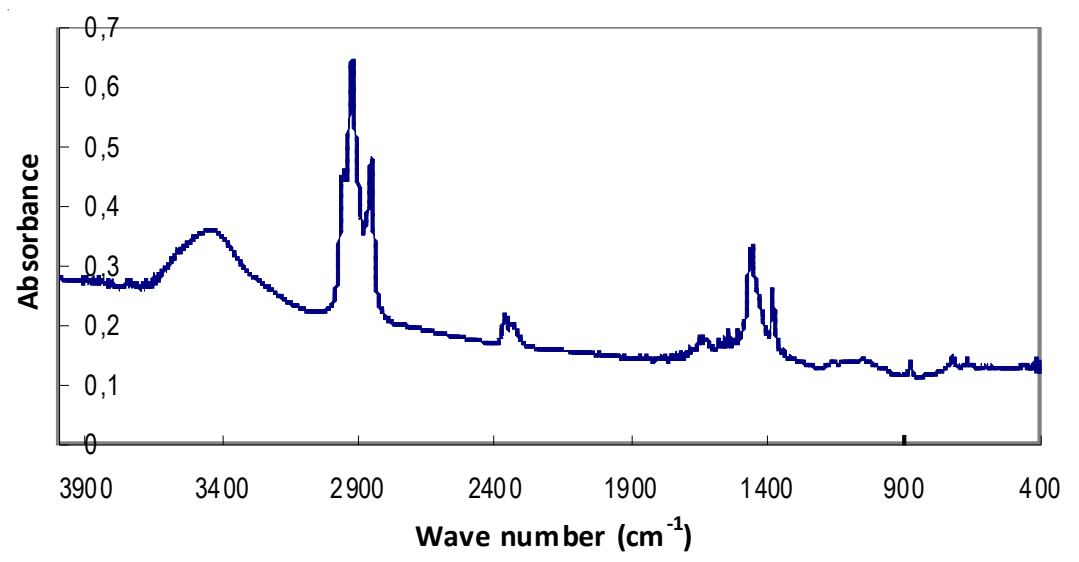

(a)

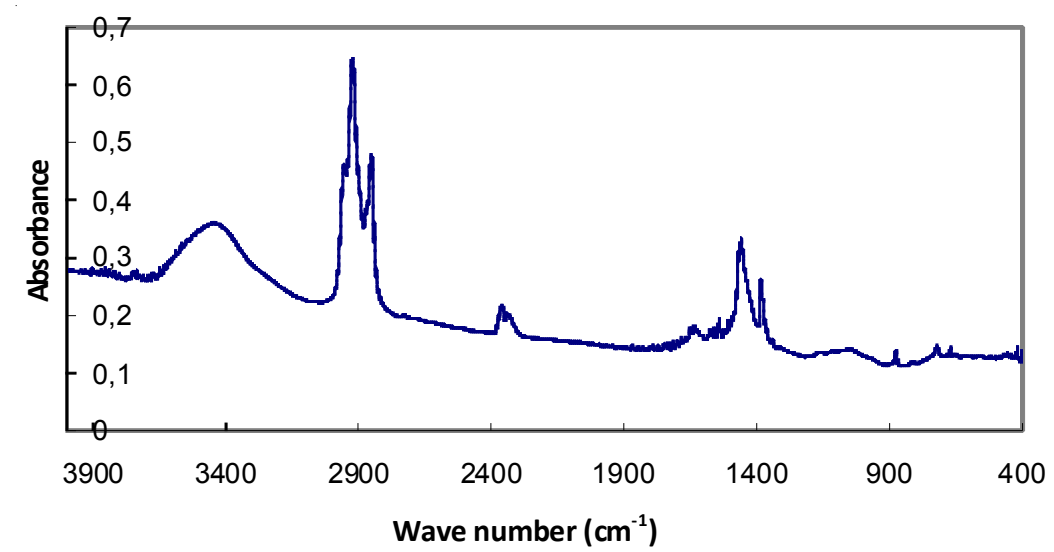

(b)

Fig. 4. FTIR spectra of lubricants with a. $1 \% \mathrm{CaSt}_{2}$ and b. $2 \% \mathrm{CaSt}_{2}$

\section{Stability of lubricants and the particle size of the $\mathrm{CaSt}_{2}$ dispersed in base oil}

The stability of the lubricant suspensions was determined by recording the height of the line separating the oil phase and the suspension phase. Due to gravity, settling the particles on the level of this line decreases continuously with time as seen in Figure 5. The settling velocity is directly proportional to the radius of the particle as shown in Equation 2 [2].

$$
d x / d t=2 r^{2}\left(\rho-\rho_{\mathrm{o}}\right) g / 9 \eta,
$$

where: $d x / d t$ is rate of settling $(\mathrm{cm} / \mathrm{s}) ; \rho_{\mathrm{o}}$ is the density of medium $\left(\mathrm{g} / \mathrm{cm}^{3}\right), \rho$ is the density of particle $\left(\mathrm{g} / \mathrm{cm}^{3}\right)$, $\eta$ is viscosity of medium $(\mathrm{g} /(\mathrm{cm} . \mathrm{s})), r$ is radius of particle $(\mathrm{cm}), g$ is $981 \mathrm{~cm} / \mathrm{s}^{2}$.

The radius of particles was calculated from the slopes of the lines in Figure 6. The results were evaluated for the settling of particles within 15 days. The oil density and viscosity used for the calculations are $0.86 \mathrm{~g} / \mathrm{cm}^{3}$ and $0.35 \mathrm{~g} /(\mathrm{cm} . \mathrm{s})$. The density of $\mathrm{CaSt}_{2}$ is $1.12 \mathrm{~g} / \mathrm{cm}^{3}$. The initial rate of settling was calculated as $0.188 \times 10^{-7} \mathrm{~cm} / \mathrm{s}$ and $0.635 \times 10^{-12} \mathrm{~cm} / \mathrm{s}$ foroils with $1 \%$ and $2 \% \mathrm{CaSt}_{2}$ respectively from Figure 6. Apparent radius of the $\mathrm{CaSt}_{2}$ particles dispersed in base oil was 1.88 $\mu \mathrm{m}$ and $0.11 \mu \mathrm{m}$ respectively for $1 \%$ and $2 \%$ $\mathrm{CaSt}_{2}$ added samples respectively. The $\mathrm{CaSt}_{2}$ particles were molten and recrystallized in base oil during preparation of the lubricant. Thus they have a different particle size than the original powder. At higher $\mathrm{CaSt}_{2}$ content, the formed $\mathrm{CaSt}_{2}$ crystals were in smaller size due to fast nucleation and slow growth of crystals. The gelation of $\mathrm{CaSt}_{2}$ and base oil system is also another possibility affecting apparent size of particles. 


\section{ТЕХНИКО-ТЕХНОЛОГИЧЕСКИЕ ИННОВАЦИИ}

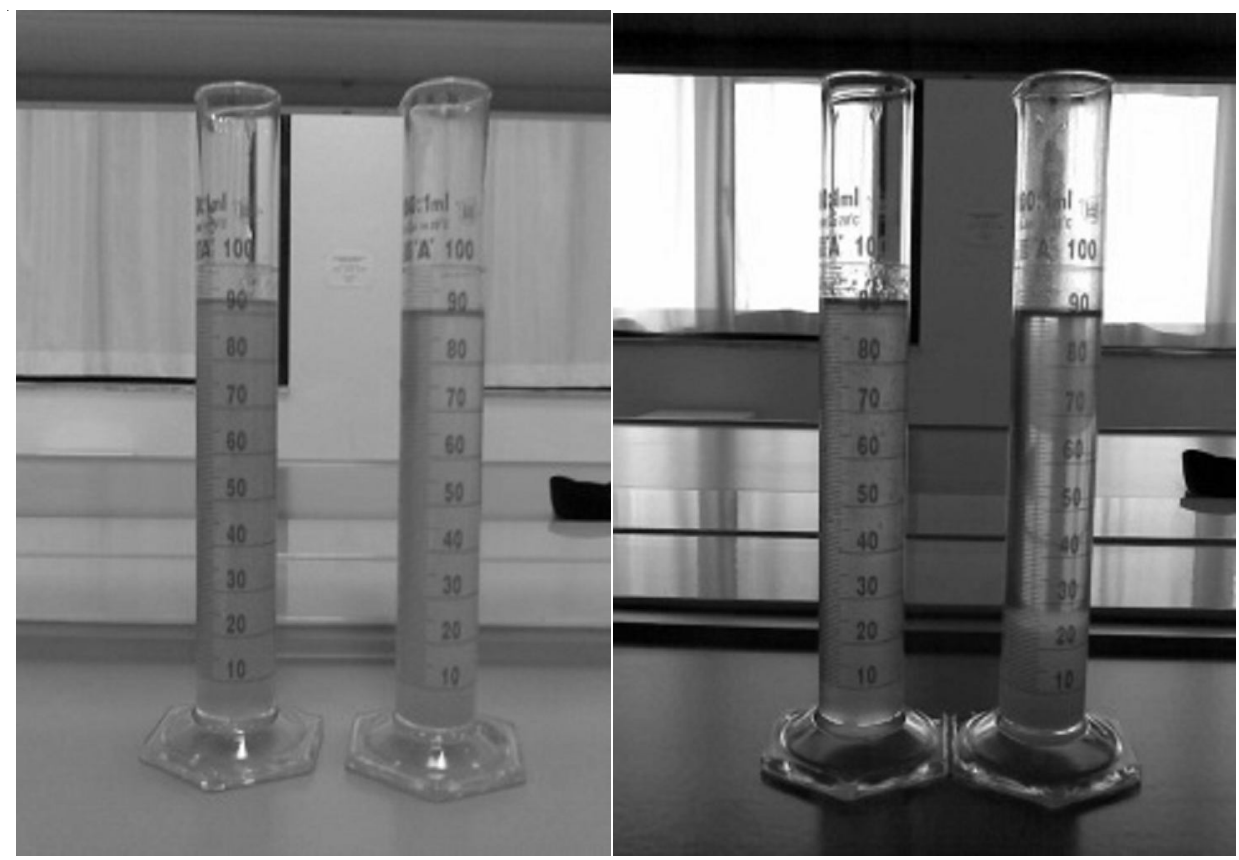

(a)

(b)

Fig. 5. Settling of $\mathrm{CaSt}_{2}$ particles in base oil on the a. $1^{\text {st }}$ day, b. $15^{\text {th }}$ day after mixing

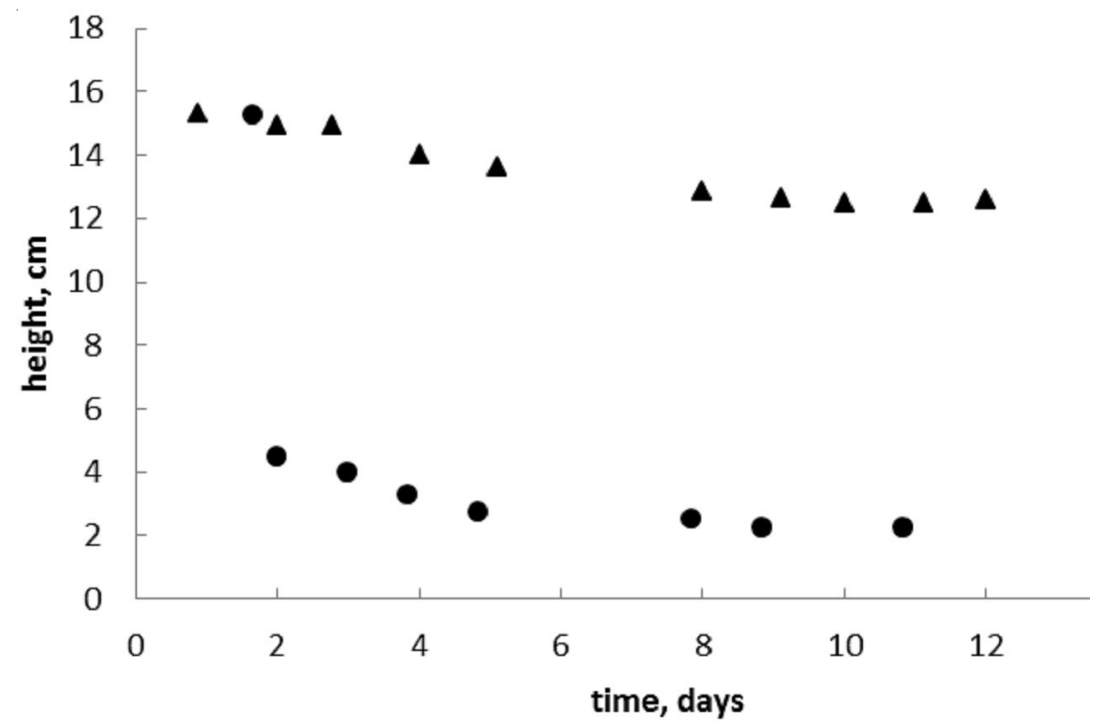

Fig. 6. The height of the boundary between clear base oil and $\mathrm{CaSt}_{2}$ particles settling in base oil

\section{Melting behavior of pure $\mathrm{CaSt}_{2}$ and $\mathrm{CaSt}_{2}$ in mineral oil}

$\mathrm{CaSt}_{2}$ powder melts at $120^{\circ} \mathrm{C}$ as determined by DSC and at $148{ }^{\circ} \mathrm{C}$ by optical microscopy in a previous study [5]. In Figure 7 micrographs of the $\mathrm{CaSt}_{2}$ powders before and after melting are seen. Before melting $\mathrm{CaSt}_{2}$ appears as a white powder and on melting it is transformed into a transparent liquid. It was found that $\mathrm{CaSt}_{2}$ had a melting temperature of $142.8{ }^{\circ} \mathrm{C}$ by optical microscopy in the present study. $\mathrm{CaSt}_{2}$ particles in base oil also showed a similar phase transition behavior as bulk $\mathrm{CaSt}_{2}$. They were dispersed as particles in base oil at room temperature. The particles kept their shape up to $113^{\circ} \mathrm{C}$ and they melted and mixed with mineral oil homogeneously at $128^{\circ} \mathrm{C}$ as seen in Figure 8 . 


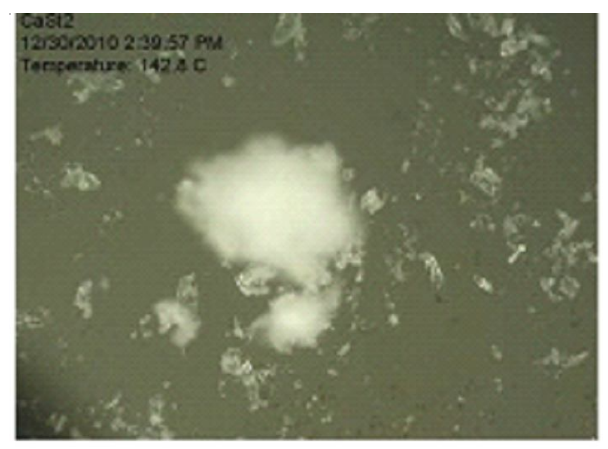

(a)

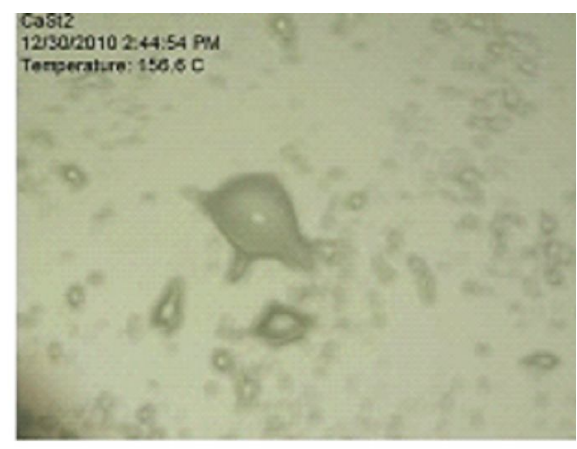

(b)

Fig. 7. Optical micrographs of CaSt ${ }_{2}$ powder at a. $142.8^{\circ} \mathrm{C}$ and b. $156.6^{\circ} \mathrm{C}$

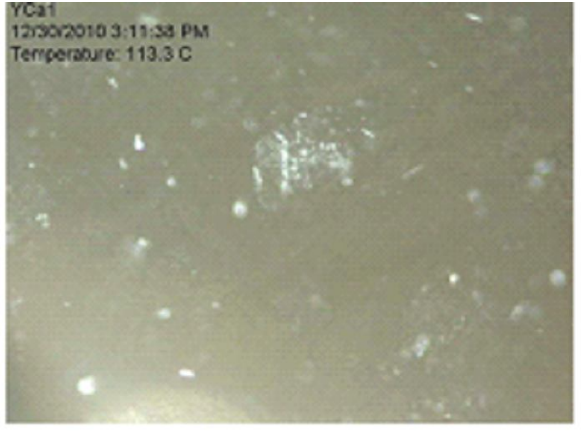

(a)

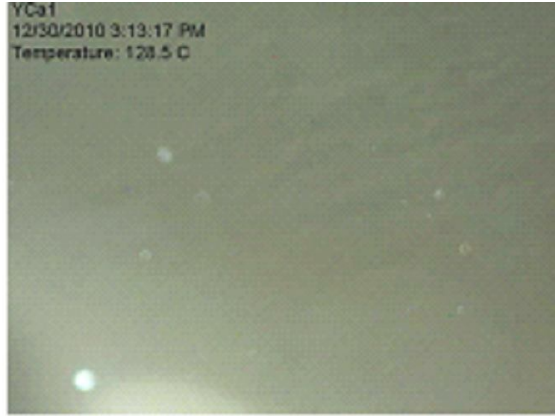

(b)

Fig. 8. Optical micrographs of $\mathrm{CaSt}_{2}(1 \%)$ dispersed in mineral oil at a. $113^{\circ} \mathrm{C}$ and b. $128^{\circ} \mathrm{C}$

\section{Friction and wear behavior of the lubricants}

The lubricants with $\mathrm{CaSt}_{2}$ efficiently decreased the friction and wear between metal surfaces. The four ball test results are shown in Table, wear scar's optical micrographs are seen in Figure 9. The friction coefficient and wear scar diameter of base oil 0.099 and $1402 \mathrm{~nm}$ were reduced to 0.0730 and $627.61 \mathrm{~nm}$ respectively for the lubricant having $1 \% \mathrm{CaSt}_{2}$. For $2 \% \mathrm{CaSt}_{2}$ containing lubricant the friction coefficient and the wear scar diameter were 0.815 and 0.540 respectively. As the $\mathrm{CaSt}_{2}$ content increased, better lubricating efficiency was observed. The four ball tests are done at $75{ }^{\circ} \mathrm{C}$. At this temperature $\mathrm{CaSt}_{2}$ is in solid form in base oil. However, by the kinetic energy of the rotating ball over fixed balls the temperature of the oil should have been increased to melt the $\mathrm{CaSt}_{2}$ crystals in base oil and to cover the surface of the balls by a smooth lubricating layer. The solid $\mathrm{CaSt}_{2}$ particles similar to other nano-particles can also fill the crevices and holes on the steel surface reducing the friction and wear.

\section{The effect of four ball tests on the color of the base oil}

The lubricants change their color due to oxidation, hydrolysis and thermal degradation during its use. Contaminants from the eroding surfaces also change the color of the oil. The solid colorants in the lubricating oil can be filtered and the filter surface color can be measured [1]. In the present study the color change of the lubricating oils during four ball tests were investigated by visible spectroscopy. The visible spectra of the lubricants shown in Figure 10 were taken using the base oil as the reference. The base oil with $1 \% \mathrm{CaSt}_{2}$ were lighter in color than the reference base oil as indicated by the negative 


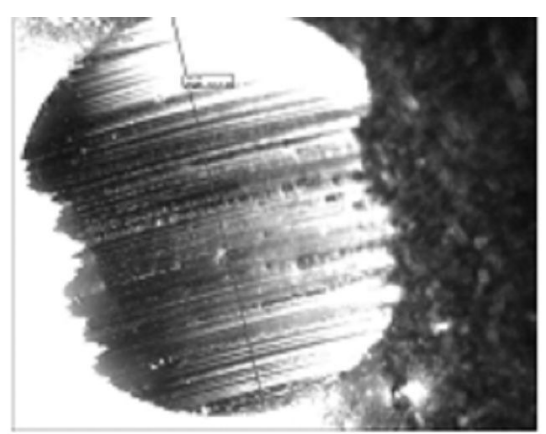

(a)

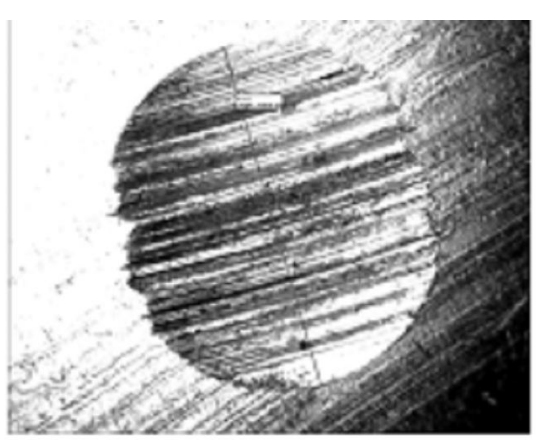

(b)

Fig. 9. Optical micrograhs of the wear scar diameters of the one of the fixed balls of four ball tests for a. $1 \% \mathrm{CaSt}_{2}$ and b. $2 \% \mathrm{CaSt}_{2}$ containing lubricant

Friction coefficient and wear scar diameter of base oil and lubricants with $1 \%$ and $2 \% \mathrm{CaSt}_{2}$

\begin{tabular}{|l|c|c|c|}
\hline \multicolumn{1}{|c|}{ Property } & Base oil [8] & $\begin{array}{c}\text { Base oil with } \\
1 \% \mathrm{CaSt}_{2}\end{array}$ & $\begin{array}{c}\text { Base oil with } \\
2 \% \mathrm{CaSt}_{2}\end{array}$ \\
\hline Friction coefficient & 0.099 & 0.0730 & 0.8150 \\
\hline Wear Scar Diameter, nm & 1402 & 627.61 & 540.88 \\
\hline
\end{tabular}

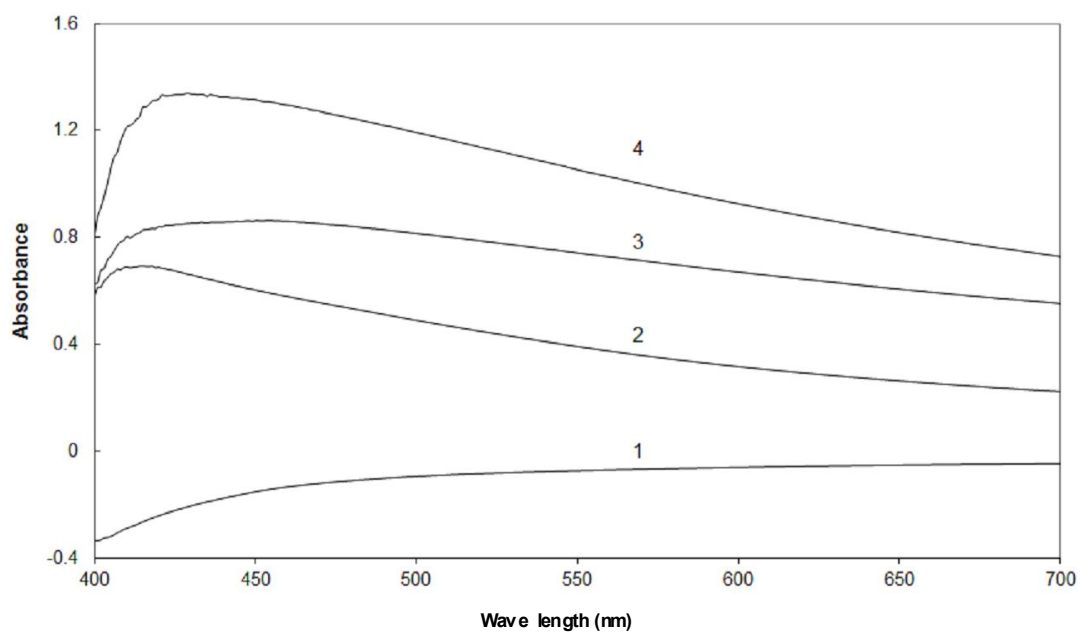

Fig. 10. Visible spectra of the base oil 1. before four ball tests, 2 . after four ball tests for $1 \% \mathrm{CaSt}_{2}$ and 3. before four ball tests and 4. after four ball tests for $2 \% \mathrm{CaSt}_{2}$

absorbance values in Figure 10. $\mathrm{CaSt}_{2}$ adsorbed the coloring material initially existing in the base oil. After four ball test, the base oil becomes dark yellow due to oxidation and crosslinking reactions in base oil. The base oil having $2 \% \mathrm{CaSt}_{2}$ had higher absorbance values at all wavelengths and the absorbance was maximum at $420 \mathrm{~nm}$. It also had a darker color after the test. Thus, $\mathrm{CaSt}_{2}$ improves the lubricating efficiency of the base oil, but it does not increase the oxidative and thermal stability. Adding antioxidants to the system would help the thermal and oxidative stability which could be the subject of further investigations. 


\title{
ТЕХНИКО-ТЕХНОЛОГИЧЕСКИЕ ИННОВАЦИИ
}

\section{CONCLUSION}

Calcium stearate powder prepared from sodium stearate and calcium chloride by precipitation from aqueous solutions and Light Neutral Base oil were mixed together to obtain lubricating oils. It was found that $\mathrm{CaSt}_{2}$ powder had a melting temperature of $142.8^{\circ} \mathrm{C}$ and in the base oil it melted at above $128^{\circ} \mathrm{C}$. From rate of settling the particles in base oil the size of dispersed particles were found to be $1.88 \mu \mathrm{m}$ and $0.11 \mu \mathrm{m}$ respectively for lubricants having $1 \%$ and $2 \%$ $\mathrm{CaSt}_{2}$. The friction coefficient (0.099) and wear scar diameter of base oil $(1402 \mathrm{~nm})$ were reduced to 0.0730 and $627.61 \mathrm{~nm}$ respectively for the lubricant having $1 \% \mathrm{CaSt}_{2}$. Lower wear scar diameter $(540 \mathrm{~nm})$ was obtained for lubricant with $2 \% \mathrm{CaSt}_{2}$. Calcium stearate when added to base oil reduces the friction and wear of metal surfaces sliding on each other. It covers the cracks and groves of the metal surface with a smooth film. Thus, it is an efficient lubricant additive. However, $\mathrm{CaSt}_{2}$ did not increase oxidative and thermal stability of the base oil. Thus, further studies for the antioxidant selection should be made.

\section{ACKNOWLEDGEMENTS}

The authors thanks the Opet Fuchs Turkey for the four ball tests.

\section{REFERENCES}

1. Akira Sasaki, Hideo Aoyama, Tomomi Honda, Yoshiro Iwai \& C. K. Yong. A Study of the Colors of Contamination in Used Oils. Tribology Transactions, 2014, no. 57, iss.1, pp. 1-10.

2. Alberty R., Silbey R.J. Physical chemistry. New York, Wiley, 1997. 950 p.

3. Felder E., Levrau C., Mantel M., Dinh NGT. Experimental Study of the Lubrication by Soaps in Stainless Steel Wire Drawing. Proceedings of The Institution of Mechanical Engineers. Part J-Journal of Engineering Tribology, 2011, no. 225(19, J9), pp. 915-923.

4. Gönen M., Öztürk S., Balköse D., Ülkü S. Preparation and Characterization of Calcium Stearate Powders and Films Prepared by Precipitation and Langmuir-Blodgett Techniques. Ind. and Eng. Chem. Res., 2010, no. 49, pp. 1732-1736.

5. Hughes E.C., Harrison M.S. US2995516 A. Cutting Oil Containing Calcium Stearate. 1956.

6. Lu Y., Miller J.D. Carboxyl Stretching Vibrations of Spontaneously Adsorbed and LB_Transferred Calcium Carboxylates as Determined by FTIR Internal Reflection Spectroscopy. J. Colloid and Interface Sci., 2002, no. 256, pp. 41-52.

7. Moreira A.P. D., Souza B.S., Teixeira A.M.R.F. Monitoring of Calcium Stearate Formation by Thermogravimetry. J. Therm. Anal. Calorim., 2009, no. 97 , pp. 647-652.

8. Palichev T., Kramis F.S., Petkov P. OperatingConservation Motor oil with Composite Additives. Oxidation Communications, 2008, no. 31 (1), pp. 223-230.

9. Savrýk A.S., Balköse D., Ülkü S. Synthesis of Zinc Borate by Inverse Emulsion Technique for Lubrication. J. Therm. Anal. Calorim., 2011, no. 104, pp. 605-612.

\section{ИННОВАЦИОННЫЕ СМАЗОЧНЫЕ МАТЕРИАЛЫ НА ОСНОВЕ КАЛЬЦИЯ}

\author{
Алаз Изер \\ Студент бакалавриата четвертого года обучения кафедры химического машиностроения \\ Измирского технологического института \\ devrimbalkose@gmail.com \\ Gulbahcekoyu Urla 2, 35430 Измир, Турция
}

\section{Тугсе Нефиз Кахоглу}

Студент бакалавриата четвертого года обучения кафедры химического машиностроения Измирского технологического института devrimbalkose@gmail.com Gulbahcekoyu Urla 2, 35430 Измир, Турция 


\section{Деврим Балкоз}

Доктор химических наук, заведующий кафедрой химического машиностроения Измирского технологического института devrimbalkose@gmail.com Gulbahcekoyu Urla 2, 35430 Измир, Турция

Аннотация. В данной работе исследовались характеристики стеарата кальция $\left(\mathrm{CaSt}_{2}\right)$ и смазок на основе стеарата кальция. Смазочные материалы на основе стеарата кальция были подготовлены из стеарата натрия и хлорида кальция осаждением от водных растворов. $\mathrm{CaSt}_{2}$ и легкая фракция сырой нефти были смешаны вместе, чтобы получить смазочные материалы. Было показано, что у $\mathrm{CaSt}_{2}$ была температура плавления $142.8^{\circ} \mathrm{C}$, что выше, чем температура плавления сырой нефти $\left(128^{\circ} \mathrm{C}\right) . \mathrm{C}$ помощью оптических микроскопов были исследованы составы полученных смазок. Было показано, что размеры рассеянных частиц были соответственно 1.88 мкм и 0.11 мкм для смазок, имеющих $1 \%$-ную и $2 \%$-ную концентрацию $\mathrm{CaSt}_{2}$. В результате испытаний на износостойкость было показано, что коэффициент трения и размер изнашивания у сырой нефти были 0.099 и 1402 нм соответственно, для смазки, имеющей $1 \%$-ный $\mathrm{CaSt}_{2}$ эти показатели были уменьшены до 0.0730 и 627.61 нм. Еще меньше размер изнашивания (540 нм) был получен для смазки с $2 \%$-ным $\mathrm{CaSt}_{2} . \mathrm{CaSt}_{2}$ улучшил смазочное свойство сырой нефти, но не улучшил ее окислительную и термическую устойчивость.

Ключевые слова: смазка, стеарат кальция, сырая нефть, коэффициент трения, температура плавления. 